\title{
METAPOPUlations AND FEEDING SElectivity OF MONTANE AND LONG-TAILED VOLES MICROTUS MONTANUS AND M. LONGICAUDUS, AND HANTAVIRUS IN THE JACKSON HOLE SMall Mammal COMMUNITY
}

\author{
FREDERICK J. JANNETT, JR. $\downarrow$ DEPARTMENT OF BIOLOGY \\ THE SCIENCE MUSEUM OF MINNESOTA $\downarrow$ ST. PAUL
}

\section{$\downarrow \quad$ OBJECTIVES}

The purposes of the long-term research on metapopulations of voles begun in 1971 are to enumerate patterns in survivorship and reproduction across the sections of the metapopulations, and concomitant variation in morphology. The study sites for Microtus montanus were chosen to represent primary and secondary habitat, and proximate and isolated habitat patches.

The purpose of the research begun in 1989 is to ascertain how selectively Microtus montanus and $M$. longicaudus feed, and to assess vegetation as a factor in demographic processes of the two species.

The purpose of the research on hantavirus begun in 1994 is to ascertain the extent of hantavirus among as many species of small mammals as possible, to identify the strain(s), to understand the presence of hantavirus across species and among the metapopulations of voles, and to assess the potential for human contact.
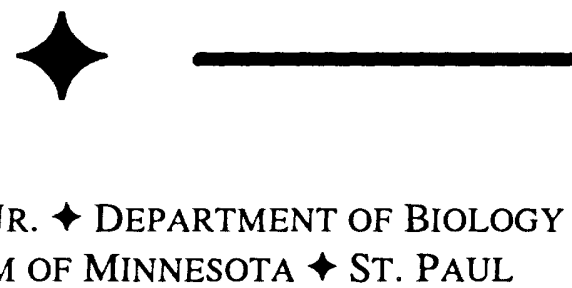

\section{$\downarrow \quad$ METHODS}

Most trapping periods were limited to two days so that impact on the respective populations would be minimized. From fresh specimens, eyes were removed for age determination upon lens weight (Gourley and Jannett, 1975).

Microtus montanus had been monitored at 18 sites annually and $M$. longicaudus at three sites during the mid-1980's through 1988. From 19891993, I continued to monitor M. montanus at three sites, and concentrated on locating additional populations of $M$. longicaudus. Monitoring $M$. montanus in 1993 was extended to a total of six known sites because populations were unusually "low".

In 1994, we undertook the standard monitoring effort at nine known populations of Microtus montanus and at two of $M$. longicaudus for long-term metapopulation data; one unstructured sample was made of one other known $M$. montanus population. No effort was made to enumerate 
additional populations of $M$. longicaudus, because the emphasis in the field effort was placed on securing as many species as possible through livetrapping for the hantavirus survey.

Specimens were secured for the hantavirus survey in the 10 long-term study populations of Microtus montanus and two long-term study populations $M$. longicaudus. They were also taken at 14 additional sites ranging as far south as Lupine Meadows and as far north as the Grassy Lake area of the Rockefeller Memorial Parkway. Collections were made in and/or around buildings at Lupine Meadows, Colter Bay, Moran junction, and the Research Station. Other collecting sites were proximate to Flagg Ranch, Elk Ranch, Leek's Marina, and the Moran grade school. For the hantavirus survey, specimens were heavily anesthetized, blood and lungs were removed and frozen, and the specimens were sacrificed. Blood was shipped to the Centers for Disease Control and Prevention where it was examined for hantavirus using ELISA. Subsequently, lungs of the respective positive specimens were forwarded for confirmation and genetic characterization by PCR.

\section{$\uparrow \quad$ RESUlTS}

In the six populations of Microtus montanus monitored in 1993 and again in 1994, numbers of voles showed disparate changes in numbers. In secondary habitat which usually has a very small number of voles in the sample, no voles were obtained. In habitat patches proximate to primary habitat, there was no change in vole numbers at one site, and increases of $3.5 \mathrm{x}$ and $5.4 \mathrm{x}$ 1993 numbers at two others. The approximate increase in numbers at the one unstructured sample in primary habitat was $2.8 \times 1993$ numbers. The change in numbers at the other primary habitat site was a decline by $0.08 \times 1993$ numbers, but that was probably largely due to snow during the sample session.

Fall breeding by Microtus montanus was evidenced by lactating and recently lactating females, but there were no pregnant females. Of the eight regularly monitored sites for $M$. montanus where voles were obtained in 1994, one or more parous females were secured at each of seven sites, but there were only three sites with an actively lactating female, none of these sites had more than one, and only one other site had recently lactating females. The sex ratios (males:females) of reproductively active and recently active voles in three samples with reproductive activity were $1: 1$, $1: 2$, and 2:1. One sample with a lactating female had no adult male. The ratios in non-reproducing populations were $1: 1 \quad(n=2$ samples $)$, or there was no male $(n=1)$.

Numbers of Microtus longicaudus were characteristically low at the two sites where they had been monitored. As is usual for this species in northern Jackson Hole in October, breeding had ceased.

Incidentally to the hantavirus survey, we found three additional population(s) of Microtus longicaudus. Two were proximate to human habitation or recent habitation. The third was in the willow-sedge community.

For hantavirus, blood was examined from 576 rodents of 12 species, from one weasel, and from 14 shrews (Table 1). The efficacy of the ELISA test for hantavirus in carnivores and shrews is problematic. Four individuals were positive. They were three Microtus montanus from two contiguous populations near Flagg Ranch, and one M. pennsylvanicus secured near the Elk Ranch. At least two of the positive individuals were parous females.

\begin{tabular}{|lc|}
\hline Table 1. Species and sample sizes for hantavirus survey. \\
\hline & Sample \\
Species & size \\
& \\
\hline & \\
Sorex spp., shrews & 14 \\
Mustela erminea, shorttail weasel & 1 \\
Tamias amoenus, yellow pine chipmunk & 78 \\
T. minimus, least chipmunk & 5 \\
Tamiasciurus hudsonicus, red squirrel & 6 \\
Thomomys talpoides, northern pocket gopher & 4 \\
Clethrionomys gapperi, boreal redback vole & 35 \\
Microtus longicaudus, longtail vole & 48 \\
M. montanus, montane vole & 211 \\
M. pennsylvanicus, meadow vole & 18 \\
M. richardsoni, Richardson vole & 1 \\
Phenacomys intermedius, heather vole & 1 \\
Peronyscus maniculatus, deer mouse & 168 \\
Erithizon dorsatum, porcupine & 1 \\
& \\
\hline
\end{tabular}


PCR examination of the lungs of serologically positive specimens has not been finished.

\section{DISCUSSION}

The numbers of Microtus montanus in the overall metapopulation increased from 1993 to 1994. Disparate trends in the smaller populations are to be expected in the respective small sample sizes.

Fall breeding was not extensive in 1994, nor would it be expected at low population numbers (Krebs and Myers, 1974). There was some support for the correlation of continued fall breeding with operational sex ratios conducive to social stimulation of breeding (Jannett, 1984a, 1984b), but more data are needed from the range of population sizes and degrees of breeding to support or falsify the hypothesis.

The finding of Microtus longicaudus in the willow-sedge community supports the suggestion by Clark and Stromberg (1987) that this species is found in various habitats. Negus and Findley (1959) had secured none of this species in 17 quadrats in nine community types. Preliminary to food habits analyses, I have now found $M$. longicaudus in the margins of open fields, in pine forest, along streams, on shaded talus, in willowsedge, on dry slopes with various vegetation communities, and in buildings.

The finding of hantavirus in voles was particularly interesting because it raises questions of what strain(s) are present, how they are distributed across the species and population segments of voles, and what effect(s) they have on individual voles and populations. Since voles are often extremely abundant near human activity in Jackson Hole, we must now address the question of what risks there are epidemiologically. That no Peromyscus maniculatus, reported to be a principal reservoir for hantavirus in the western United States (Childs et al., 1994), was found to be positive was surprising. However, evidence is accumulating that older individuals within a population are more likely than younger animals to test positive (Mills, personal communication). Since the samples we collected in October were composed largely of subadults, incidence would be expected to be relatively low.
We plan to sample and test rodents in 1995 from both July, when older individuals should be more abundant, and October. Collection of $P$. maniculatus in buildings with human habitation will be expanded.

\section{SPECIMEN DEPOSITION}

Specimens collected are in the collections of the Science Museum of Minnesota. Lung tissue of serologically negative specimens are in the frozen tissue collection of the Bell Museum of Natural History, St. Paul.

\section{ACKNOWLEDGEMENTS}

I thank Grand Teton National Park for permission to work in the Park, and the University of Wyoming-National Park Service Research Center for its hospitality, for the use of traps, and for financial assistance. This work was supported by the University of Wyoming-National Park Service Research Center, the Science Museum of Minnesota, and the Centers for Disease Control and Prevention. I thank Neil J. Vanderbosch for assistance in the field.

\section{LITERATURE CITED}

Childs, J. E., T. G. Ksiazek, C. F. Spiropoulou, J. W. Krebs, S. Morzunov, G. O. Maupin, K. L. Gage, P. E. Rollin, J. Sarisky, R. E. Enscore, J. K. Frey, C. J. Peters, and S. T. Nichol. 1994. Serologic and genetic identification of Peromyscus maniculatus as the primary rodent reservoir for a new hantavirus in the southwestern United States. J. Infec. Dis., 169: 1271-1280.

Clark, T. W. and M. R. Stromberg. 1987. Mammals in Wyoming. University of Kansas, Mus. Nat. Hist., Publ. Ed. Ser. No. 10,314 pp.

Gourley, R. S. and F. J. Jannett, Jr. 1975. Pine and montane vole age estimates from eye lens weights. J. Wildl. Manage., 39: 550556. 
Jannett, F. J., Jr. 1984a. Reproduction of the montane vole, Microtus montanus, in subnivean populations. Special Publ. Carnegie Mus. Nat. Hist., 10: 215-224.

Jannett, F. J., Jr. 1984b. Sex ratios and late fall breeding in the montane vole, Microtus montanus. Amer. Zool., 24: 3A.
Krebs, C. J. and J. H. Myers. 1974. Population cycles in small mammals. Adv. Ecol. Res., 8: 267-399.

Negus, N. C. and J. S. Findley. 1959. Mammals of Jackson Hole, Wyoming. J. Mamm., 40: $371-381$. 